with integrated addiction and medical treatment for those with chronic medical conditions. ${ }^{14}$

This examination of respiratory diseases among drug users ${ }^{9}$ adds further strength to the premise that, given the frequency of overlapping drug use and medical co-morbidities, improvements in these health domains will likely require health professionals to be cognisant of both, in the quest to address either optimally.

Conflicts of interest The authors declare that they have no conflicts of interest in relation to this article.

Contributorship Both authors have contributed significantly to the writing and editing of the manuscript, and have approved this manuscript.

Commissioned article; not externally peer-reviewed; accepted 28th October 2012; online 8th November 2012

(c) 2012 Primary Care Respiratory Society UK. All rights reserved

http://dx.doi.org/10.4104/pcrj.2012.00094

Prim Care Respir J 2012; 21(4): 364-365

\section{References}

1. De Alba, Samet JH, Saitz R. Burden of medical illness in drug- and alcoholdependent persons without primary care. Am J Addict 2004;13(1):33-45 http://dx.doi.org/l10.1080/10550490490265307

2. Fareed A, Musselman D, Byrd-Sellers J, et al. On-site Basic Health Screening and Brief Health Counseling of Chronic Medical Conditions for Veterans in Methadone Maintenance Treatment. J Addict Med 2010;4(3):160-6.

http://dx.doi.org/10.1097/ADM.0b013e3181b6f4e5

3. Mertens JR, Lu YW, Parthasarathy S, Moore C, Weisner CM. Medical and psychiatric conditions of alcohol and drug treatment patients in an HMO: comparison with matched controls. Arch Intern Med 2003;163(20):2511-17. http://dx.doi.org/10.1001/archinte.163.20.2511

4. Reif S, Larson MJ, Cheng DM, Allensworth-Davies D, Samet J, Saitz R. Chronic disease and recent addiction treatment utilization among alcohol and drug dependent adults. Subst Abuse Treat Prev Policy 2011;6:28.
http://dx.doi.org/10.1186/1747-597X-6-28

5. O'Donnell AE, Pappas LS. Pulmonary complications of intravenous drug abuse. Experience at an inner-city hospital. Chest 1988;94(2):251-3. http://dx.doi.org/10.1378/chest.94.2.251

6. Gordon RJ, Lowy FD. Bacterial infections in drug users. N Engl I Med 2005;353(18):1945-54. http://dx.doi.org/10.1056/NEJMra042823

7. Baxter JD, Samnaliev M, Clark RE. The quality of asthma care among adults with substance-related disorders and adults with mental illness. Psychiatr Serv 2009;60(1):43-9. http://dx.doi.org/10.1176/appi.ps.60.1.43

8. Lasser KE, Kim TW, Alford DP, Cabral H, Saitz R, Samet JH. Is unhealthy substance use associated with failure to receive cancer screening and flu vaccination? A retrospective cross-sectional study. BMJ Open 2011;1(1):e000046. http://dx.doi.org/10.1136/bmjopen-2010-000046

9. Palmer F, Jaffray M, Moffat MA, Matheson C, McLernon DJ, Coutts A, Haughney J. Prevalence of common chronic respiratory diseases in drug misusers: a cohort study. Prim Care Respir J 2012;21(4):377-83. http://dx.doi.org/10.4104/pcrj.2012.00069

10. Jones $R$, Østrem A. Optimising pharmacological maintenance treatment for COPD in primary care. Prim Care Respir J 2011;20(1):33-45. http://dx.doi.org/10.4104/pcri.2010.00069

11. Institute of Medicine. Improving the Quality of Health Care for Mental and Substance-Use Conditions: Quality Chasm Series. 1st ed. National Academies Press; 2006.

12. Samet JH, Friedmann P, Saitz R. Benefits of linking primary medical care and substance abuse services: patient, provider, and societal perspectives. Arch Intern Med 2001;161(1):85-91.

http://dx.doi.org/10-1001/pubs.Arch Intern Med.-ISSN-0003-9926-161-1-ioi00065.

13. Samet JH, Larson MJ, Horton NJ, Doyle K, Winter M, Saitz R. Linking alcohol- and drug-dependent adults to primary medical care: a randomized controlled trial of a multi-disciplinary health intervention in a detoxification unit. Addiction 2003;98(4):509-16. http://dx.doi.org/10.1046/j.1360-0443.2003.00328.x

14. Weisner C, Mertens J, Parthasarathy S, Moore C, Lu Y. Integrating primary medical care with addiction treatment: a randomized controlled trial. JAMA 2001;286(14):1715-23. http://dx.doi.org/10.1001/jama.286.14.1715

\title{
Adolescents and anaphylaxis
}

\section{See linked article by Gallagher et al. on pg 392}

\section{*Richard F Lockey}

1 Distinguished University Health Professor; Professor of Medicine, Pediatrics \& Public Health; Director, Division of Allergy \& Immunology; Joy McCann Culverhouse Professor of Allergy \& Immunology, University of South Florida College of Medicine, USA

*Correspondence: Professor Richard F Lockey, Culverhouse Professor of Allergy \& Immunology, University of South Florida College of Medicine, c/o VA Hospital, 13000 Bruce B.Downs Blvd (111D), Tampa, FL 33612, USA

Tel: +1 (813) 972-7631 Fax: +1 (813) 910-4041

E-mail: rlockey@health.usf.edu

The article by Gallagher et al. ${ }^{1}$ in this issue of the $P C R J$ is of particular interest, not least because the authors studied 26 adolescents (aged 13 to 19 years) at risk for anaphylaxis and did not find the "rebel without a cause" mentality as the dominant reason why this age group is three to four times more likely to die than children because they take risks and have accidents. ${ }^{2}$ The movie, "Rebel Without a Cause", starring James Dean, was released by Warner Bros on 27th October 1955, less than one month after the famous actor's fatal car crash. In this controversial movie of the time, Jim Stark (played by James Dean) is a rebellious 17-year-old teenager caught up in family discord who disobeys his parents, defies the local schoolboys, and confronts the differences and conflicts between generations. ${ }^{3}$ One would think that teenagers susceptible to anaphylaxis would possess the James Dean-like rebellious personality, thereby accounting for the fact that adolescents with this disease are at increased risk of fatal outcomes.

However, just the opposite was found in this study. The majority of episodes of anaphylaxis, primarily from food allergies (in particular, peanuts and tree nuts) but also due to fish, shellfish, sesame seed, dairy, lentils, milk, egg, tomato and other fleshy fruits, legumes and insects, horse and idiopathic, "...did not result from stereotypically irresponsible behavior (such as alcohol misuse or deliberate exposure to known allergens)."1 The authors found that most adolescents, as did their parents, took an active role in managing their risk of anaphylaxis. Some parents and adolescents emphasised the idea that 
there was a need not to allow this risk to dominate their lives, i.e. they want to live as normal a life as possible.

Both adolescents and parents found the risks of ingesting the foods to which they are allergic somewhat difficult to judge, and "Most adolescents ate trace-labeled foods and several ate Asian food, not realising the dangers".' Both parents and adolescents reported variable or no support from patient care groups, specialists and primary care physicians. Likewise, most patients did not feel that written plans were very useful or practical. So, to reiterate, these authors found decent compliance for avoidance and treatment of food-induced anaphylaxis by both the adolescent patient and his/her parents. Most anaphylactic reactions resulted from accidents, misinformation or inexperience.

Up to 200 food allergic deaths occur in the USA per year, a high proportion of which involve teenagers and young adults. Even though the paper by Gallagher and colleagues is somewhat reassuring about risk-management by this age group,' not all studies concur with their findings. ${ }^{48}$ For example, several articles, including the study by Sampson et al. of 174 adolescents and young adults (mean age, 16 years; range 13 to 21 years), indicate that a considerable amount of risk was noted in "always carrying" self-injectable epinephrine and purposely exposing themselves to a potentially unsafe food.

"Neuroscientists probing the teen brain have found that it undergoes a major remodeling that may be responsible for the teenager's propensity to take risks, seek out new experiences and fail to restrain inappropriate responses". ${ }^{9}$ Even though the authors did not find that these factors played a major role in this study, ${ }^{1}$ one wonders whether the teenagers interviewed by Gallagher et al. accurately and correctly answered the interview questions as provided in the paper. Were they 'acting out' in answering many of the questions? - i.e. providing a more ideal answer than the one they would more likely have given to their peer group.

In any event, it matters little. The teenager is at highest risk for anaphylactic death, just as he or she is at highest risk for accidental death. ${ }^{2}$ Therefore, adolescents require special attention by physicians and other healthcare professionals. Professionals who work with them in chronic disease clinics know how difficult it is for many in this group to adjust to the changes necessary to cope with their illness - in particular, a chronic illness.

The question, therefore, is how best to assure adherence to programs to prevent allergen-induced anaphylaxis, particularly in the adolescent age group. Firstly, making an appropriate diagnosis, by taking a complete history and performing a physical examination, is fundamental to the practice of medicine. After all, this is how any physician ultimately makes a diagnosis of an illness, in this case anaphylaxis, and suspects its aetiology. Secondly, and equally important, is educating the patient repeatedly to assure avoidance and compliance with the prescribed program, including the appropriate use of epinephrine. Thirdly, electronic social media would appear to be an excellent way for patients to interact and exchange experiences, particularly with adolescents who have similar medical problems. However, it may not be as practical as it would seem, since the adolescent may try to blend with the normal peer group and not identify or interact with a disease-oriented group. More studies are needed to determine if this form of interaction and education is useful in decreasing morbidity and mortality from allergen-induced anaphylaxis.

This article by Gallagher and colleagues is reassuring in that it shows the rebellious attitude of adolescents is not necessarily the main reason why there are still problems with avoidance and compliance with allergen-induced anaphylaxis. 'It also is reassuring to show that this group of adolescents performed fairly well in carrying on with normal lives, in spite of a potentially life-threatening disease. The underlying message is that a simplified educational program by physicians and other healthcare professionals is of paramount importance for any age group, particularly this one. There is a need to identify and train individuals who are capable of developing more effective ways to bond with the adolescent age group. This may well be the best way to achieve better outcomes.

Conflicts of interest The author declares that he has no conflicts of interest in relation to this article.

Commissioned article; not externally peer-reviewed; accepted 5th October 2012; online 22nd October 2012

(c) 2012 Primary Care Respiratory Society UK. All rights reserved http://dx.doi.org/10.4104/pcrj.2012.00090

Prim Care Respir J 2012: 21(4): 365-366

\section{References}

1. Gallagher M, Worth A, Cunningham-Burley S, Sheikh A. Strategies for living with the risk of anaphylaxis in adolescence: qualitative study of young people and their parents. Prim Care Respir J 2012;21(4):392-7.

http://dx.doi.org/10.4104/pcrj.2012.00072.

2. Hoyert DL, Heron MP, Murphy SL, Kung HC. Deaths - Final Data for 2003. Natl Vital Stat Rep 2006;54(13):1-120.

3. Wikipedia. Rebel Without a Cause. Last modified 29 September 2012. http://en.wikipedia.org/wiki/Rebel_without_a_cause

4. Sampson MA, Muñoz-Furlong A, Sicherer SH. Risk-taking and coping strategies of adolescents and young adults with food allergy. J Allergy Clin Immunol 2006; 117(6):1440-45. http://dx.doi.org/10.1016/j.jaci.2006.03.009

5. Akeson A, Worth A, Sheikh A. The psychosocial impact of anaphylaxis on young people and their parents. Clin Exp Allergy 2007;37(8):1213-20. http://dx.doi.org/10.1111/j.1365-2222.2007.02758.x

6. Greenhawt MJ, Singer AM, Baptist AP. Food allergy and food allergy attitudes among college students. J Allergy Clin Immunol 2009;124(2):323-27. http://dx.doi.org/10.1016/j.jaci.2009.05.028

7. Noimark L, Wales J, Du Toit G, Pastacaldi C, et al. The use of adrenaline autoinjectors by children and teenagers. Clin Exp Allergy 2012;42(2):284-92. http://dx.doi.org/10.1111/j.1365-2222.2011.03912.x

8. Monks H, Gowland MH, MacKenzie $\mathrm{H}$, et al. How do teenagers manage their food allergies? Clin Exp Allergy 2010;40(10):1533-40.

http://dx.doi.org/10.1111/j.1365-2222.2010.03586.x

9. Powell K. How does the teenage brain work? Nature 2006;442(7105):865-7. http://dx.doi.org/10.1038/442865a 